\title{
IMPLEMENTATION OF GOOD GOVERNANCE TO IMPROVE THE PERFORMANCE OF VILLAGE GOVERNMENTS
}

\author{
Yesi Mutia Basri*1), Tusanti Igus Findayani2), Arumega Zarefar ${ }^{3)}$ \\ Program Studi Akuntansi, Universitas Riau ${ }^{123)}$ \\ yesimutia@gmail.com ${ }^{l)}$,tusanti.gusfindayani@gmail.com ${ }^{2),}$ arumegazarefar.akt@gmail.com ${ }^{3)}$
}

\begin{abstract}
Law No. 6 of 2014 concerning villages is the starting point for villages to manage their government independently. However, in the management of government, many villages are still weak in implementing good governance, so that it has an impact on their performance. This study specifically wants to examine the role of good governance in improving the performance of village governments. This study examines the principles of good governance, transparency, accountability, community participation and fairness towards village government performance. The population of this research is the village government in the Meranti Islands Regency. The sampling technique used was area sampling, so that a total sample size of 31 villages was obtained in Tebing Tinggi, Tebing Tinggi Barat and Rangsang Barat, Meranti Islands Regency. Data was collected through a survey by distributing questionnaires to respondents consisting of the village head, village secretary, head of financial affairs and head of general affairs. The analytical method used in this study is multiple regression analysis with the help of SPSS version 23.0. The results showed that transparency, accountability, community participation and justice had a positive effect on the performance of the village government. This indicates that increased transparency, accountability, community participation and justice will improve the performance of village government in Meranti Regency. The research supports the stewardship theory that the village government will act to fulfill the interests of the village community.
\end{abstract}

Keywords: Transparency, Accountability, Community Participation, Justice, Village Government Performance.

*Corresponding author

Email: yesimutia@gmail.com

DOI: https://doi.org/10.33369/j.akuntansi.11.2.123-136

\section{INTRODUCTION}

The passing of law no. 6 of 2014 concerning Villages, gave birth to a village government that was given the authority to take care of itself. To carry out development in villages, the central government has allocated $10 \%$ of the APBN for each village in the form of Village Funds (DD). In addition, villages also receive Village Fund Allocation (ADD) which comes from the APBD from the District Government. This certainly has a positive impact on the village to be able to manage its government independently. Villages can carry out their development without depending on the central government or local governments. Thus, it is hoped that there will be equitable development down to the village level.

In fact, large funds are not always directly proportional to the performance of the village government and the welfare of the village community. Theoretically, the impact of village budget autonomy on village development has not been proven. This is because village development should have a direct impact on improving the welfare of the community in the village. The results of the study (TNP2K, 2020) show that village development does not have a significant impact on the progress of village development. This clearly reflects that the performance of the village government in implementing development is still not optimal.

In Riau Province, Meranti Regency is included in the category of the poorest local government with a poverty index of 25.28 percent in 2020 . The village funds disbursed since 2015 have not been able to improve the welfare of the people in villages in Meranti Regency. One of the factors lies in the poor infrastructure (Tolok, 2021). The lack of infrastructure in the village shows that the performance of the village government is still low. The existing village funds have no impact on the welfare of the surrounding community. 
The main factor that causes the low performance of the village government is the lack of good governance in managing village finances. The emergence of problems of corruption, transparency and low accountability are the main problems in the management of Village Government ((Nafidah \& Anisa, 2017); (Kholmi, 2017); (Sukmawati \& Nurfitriani, 2019);(Arthana, 2019); (Soukotta \& Utami, 2019). Many village heads commit fraudulent actions against village funds. It was found that as many as 473 village heads in Indonesia stumbled upon legal problems in the misuse of village funds for the 2015-2019 period (Antara, 2020). These cases reflect the weak implementation of good governance, especially in the principle of accountability. The demands of good governance from various circles have caused the village to make improvements in order to realize good governance in village governance. Good governance is a necessity that is not only addressed to business organizations, but also to all lines of government including villages. Good governance will not only create a clean and accountable government, but will also have an impact on improving the performance of village government.

According to government regulation No. 101 of 2000, Good Governance is a government that can develop and establish the principles of professionalism, accountability, transparency, excellent service, democracy, efficiency, effectiveness, rule of law and can be accepted by the whole community. Governance is the key to growth and development (Dayanandan, 2013). Therefore, it is very important for the government to implement good governance to achieve good performance.

Previous research has proven that the implementation of good governance can improve company performance (ex (Ferial et al., 2016)(Fatimah et al., 2017);(Nasrun, 2019);(Supriatna \& M. Kusuma, 2009). In public sector organizations, research on good governance has mostly focused on local governments (Susanti, 2014), (Sukmawati \& Nurfitriani, 2019), (Jatmiko \& Lestiawan, 2016), (Indriana, 2019). The results show an increase in the government's financial performance by implementing good governance.

This study examines the principles of good governance consisting of transparency, accountability, community participation and fairness of village government performance. According to Adrianto (2007) transparency is openness in earnest, comprehensive and provides a place for active participation from all levels of society in the process of managing public resources. Transparency is a principle that opens itself to the right of the community to obtain correct, honest and non-discriminatory information about the administration of Village Government while still taking into account the provisions of the legislation. According to stewardship theory, the village government as the party entrusted with the mandate by the community has a goal to improve the welfare of the community. Therefore, the village government must disclose material and relevant information about the village government. The more open the village government to the community.

Therefore, the village government must disclose material and relevant information about the village government. The more open the village government to the community regarding the implementation of activities in the village, the community believes and does not expect negative things from the village government so that this can improve the performance of the village government. The transparency can improve local government performance (Setiawan \& Safri, 2016) (Novatiani et al., 2019). However, the results of research Nasution (2018) show that transparency actually has a negative effect on government performance.

Accountability is an important element and becomes a principle in the context of the realization of good governance. With the realization of accountability, it becomes a must for every government to account for the mandate received in accordance with democratic principles. This confirms that the implementation of accountability will improve the performance of the village government. The existence of accountability in the administration 
of village government provides an opportunity for the community to know and control starting from budgeting and implementing activities. The village government must be able to account for and provide information to the community regarding governance which causes the government to try to always provide its best performance because it will be assessed and monitored by the community. Based on research conducted by Pande \& Putra (2017); Setiawan \& Safri (2016); Jitmau et al. (2017) shows that public accountability has a significant effect on government performance. However, research (Arifani et al., 2018) on the Jayapura government shows that accountability has no effect on budget performance.

The principle of participation is key in an organization, both private and public. Participation prioritizes stakeholder involvement in various organizational affairs, in problem solving solutions or in other matters aimed at advancing organizational performance. That means, the more active the community in the process of administering the government, the more successful the implementation of autonomy in a village will be, and when autonomy in a village can be achieved it will encourage the village government to seek better performance. Research of Putra (2018) on SKPD in Jambi Province shows that the principle of accountability has a significant effect on government performance and public services, but the results of this study are different from the research of Jatmiko \& Lestiawan (2016) in the Gunung Kidul Regency Government which found that the principles of transparency, accountability and society has no effect on local government performance, while justice has a significant influence on local government performance affect local government performance.

The principle of justice is fair and equal treatment of the community in providing services that do not discriminate and do not discriminate against the people served. A just government will provide equal opportunities for all people to improve and maintain the quality of life. Justice is the ability of the government in the welfare of the community in relation to its rights and obligations. If the principle of justice is applied properly by the government, the public's trust will be higher in the government so that the government's performance will be better. The results of the study Jatmiko \& Lestiawan (2016) show that justice has an effect on government performance.

Most studies still show inconsistent results. This research is also carried out in different types of organizations so that this research is still interesting to study. This study aims to analyze the effect of applying the principles of good governance on the performance of village government. This research is different from previous research Putra (2018); Pande \& Putra, (2017) which only examines several principles of good governance, namely accountability and transparency. This study expands the use of the principles of good governance, namely transparency, accountability, community participation, and justice. This research is also unique from other studies that examine the application of good governance principles in village governance in Meranti district. Previous research was mostly conducted on companies and local governments.

There has not been much research on the implementation of good governance in village government. In fact, since the birth of Law Number 6 of 2014, the Village Government has been required to implement good governance. To build a good government, it is non-negotiable and absolutely must be fulfilled. The principles of good governance include accountability, openness and transparency, as well as public participation and justice. This research has contributed to the village government to be able to implement good governance so as to improve its performance.

$\mathrm{H}_{1}$ : Transparency has a positive effect on the performance of the village government.

$\mathrm{H}_{2}$ : Accountability has a positive effect on the performance of the village government.

$\mathrm{H}_{3}$ : Community participation has a positive effect on the performance of the village government.

$\mathrm{H}_{4}$ : Justice has a positive effect on the performance of the village government. 


\section{RESEARCH METHODS}

The population used in this study is the Village Government in the Meranti Islands Regency, amounting to 101 villages. The sampling technique used was area sampling. The sample used is the villages in Tebing Tinggi, Tebing Tinggi Barat and Rangsang Barat, Kepulauan Meranti, totaling 31 villages. Respondents in this study were village managers consisting of the Village Head, Village Secretary, Head of Financial Affairs, and Head of General Affairs. The data collection technique used in this study was a questionnaire. Questionnaire. The questionnaire was delivered directly to the respondents in the study and picked up again according to the agreed time, the research time was about 2 months.

\section{Operational Definition and Variable Measurement}

According to Mahsum (2012: 141) "Performance is a description of the level of achievement of the implementation of an activity/program/policy in realizing the goals, objectives, mission and vision of the organization as stated in the strategic planning of an organization. The term performance is often used to describe achievement and if the members/employees are good and qualified then the performance of the local government will be good and quality too". Performance variables use instruments developed by Bastian \& Suryadi (2006). This statement is measured using the indicators Input, Output, Outcome, Benefit, Impact.

\section{Transparency}

Transparency can be defined as the openness of information, both in the decisionmaking process and in disclosing relevant material and information about an organization. In (Jatmiko \& Lestiawan, 2016), "Transparency is an effort that deliberately provides all information that can be issued legally, both positive and negative, that is accurate, timely, balanced and firm, with the aim of improving public reasoning skills and maintaining organizational responsibility. for his actions, policies and practices". The transparency variable uses an instrument developed by Mahoney (1963) which is used in the study (Pertiwi, 2015). The indicators used are Ease of access to information, Increased flow of information through collaboration with the mass media and non-governmental organizations, Providers of clear information about responsibility.

\section{Accountability}

According to Mardiasmo (2018: 20) "public accountability is the obligation of the trustee (agent) to provide accountability, present, report, and disclose all activities and activities that are accountable to the principal who has the right and authority to hold him accountable. Public accountability consists of two types, namely: (1) vertical accountability, and (2) horizontal accountability". The accountability variable uses indicators: legal honesty and accountability, process accountability, policy accountability.

\section{Community Participation}

According to Mardikanto \& Soebianto (2001) community participation is a form of community concern and responsibility for the importance of development which aims to improve their quality of life. Community participation is measured by using the indicator Community involvement to provide input in the formulation of the direction and general policy of the APBDes, Input and criticism from the community on the priorities and plans of the APBDes, Community involvement in the preparation of the APBDes, Community involvement in APBDes advocacy, Community involvement in consultations and confirmation between councils and local governments regarding the draft APBDes, criticisms and suggestions from 
the public in revising the APBDes. If there is a change in policies related to the APBDes. The indicators used to measure the Community Participation variable refer to the research of Sopanah \& Mardiasmo (2003).

\section{Justice}

According to KNKG (National Committee for Governance Policy) in Kuswanto (2016) justice contains an element of honesty so that in its implementation, equal treatment of stakeholders can be realized in a responsible manner". Justice is measured through three dimensions developed by Mahoney (1963), distributive justice, procedural justice, which focuses on justice that should be accepted by society, Interactional justice which focuses on responses that are addressed by a government when dealing with people who file complaints. All of these variables use a 5 (five) point Likert scale where point 1 (one) shows very little, point 2 (two) shows a little, point 3 (three) shows half, point 4 (four) shows a lot, and point 5 (five) shows very much.

\section{Data analysis method}

Hypothesis testing in this study uses Multiple Linier Regression Analysis. Multiple linear regression analysis is an analysis to measure the amount of influence between two or more independent variables on one dependent variable or predict the dependent variable using the independent variable.

The equation for multiple linear regression analysis is as follows:

$\mathrm{Y}=\alpha+\mathrm{b}_{1} \mathrm{X}_{1}+\mathrm{b}_{2} \mathrm{X}_{2}+\mathrm{b}_{3} \mathrm{X}_{3}+\mathrm{b}_{4} \mathrm{X}_{4}+\mathrm{e}$

Information:

$\mathrm{Y}=$ Village Government Performance

$\alpha=$ Constant

$\mathrm{X}_{1}=$ Transparency

$\mathrm{X}_{2}=$ Accountability

$\mathrm{X}_{3}=$ Community Participation

$\mathrm{X}_{4}=$ Justice

b $(1,2,3,4)=$ Regression Coefficient

$\mathrm{e}=$ Confounding Factor (Error)

\section{RESULTS AND DISCUSSION}

Of the 124 questionnaires distributed, 115 questionnaires were returned with the following characteristics of the respondents:

Table 1. Characteristics of Respondents

\begin{tabular}{lcc}
\hline \multicolumn{1}{c}{ Explanation } & Total & Percentage \\
\hline Sex : & & \\
Male & 91 & $79.1 \%$ \\
Female & 24 & $20.9 \%$ \\
Age: & & \\
\hline 25 years & 11 & $9.5 \%$ \\
26-35 years & 34 & $29.6 \%$ \\
36-55 years & 63 & $54.8 \%$ \\
$>55$ years & 7 & $6.1 \%$ \\
Education: & 3 & \\
Junior High School & 70 & $2.6 \%$ \\
High School & 14 & $60.9 \%$ \\
Diploma & 26 & $12.2 \%$ \\
Bachelor & & $22.6 \%$
\end{tabular}


IMPLEMENTATION OF GOOD GOVERNANCE TO IMPROVE THE PERFORMANCE OF VILLAGE GOVERNMENTS

Yesi Mutia Basri, Tusanti Igus Findayani and Arumega Zarefar

\begin{tabular}{lcc}
\hline \multicolumn{1}{c}{ Explanation } & Total & Percentage \\
\hline Master & 2 & $1.7 \%$ \\
Length of work: & & \\
\hline$<1$ years & 17 & $14.8 \%$ \\
1-5 years & 62 & $53.9 \%$ \\
6-10 years & 22 & $19.1 \%$ \\
10-15 years & 10 & $8.7 \%$ \\
$>15$ years & 4 & $3.5 \%$ \\
\hline
\end{tabular}

Source: primary data processed

From table 1 it can be seen that the difference in the number of male and female respondents, where male respondents are more than female respondents. Male respondents were $79.1 \%$ while female respondents were $20.9 \%$. The age range of 36 years-55 years was $54.8 \%$. Then when viewed from the level of education, the majority of village governments in Meranti Islands Regency have high school education / equivalent, as many as $60.9 \%$.

\section{Descriptive statistics}

Descriptive statistical presentation includes min, max, mean and standard deviation of a variable. The results of descriptive statistics can be seen in the table below:

Table 2. Descriptive Statistics of Research Variables

\begin{tabular}{lccccc}
\hline & $\mathrm{N}$ & Minimum & Maximum & Mean & $\begin{array}{c}\text { Std. } \\
\text { Deviation }\end{array}$ \\
\hline $\begin{array}{l}\text { Village Government } \\
\text { Performance }\end{array}$ & 115 & 34.00 & 5.00 & 45.64 & 2.81 \\
\hline Transparency & 115 & 24.00 & 38.00 & 25. & 2.22 \\
\hline Accountability & 115 & 31.00 & 45.00 & 37.70 & 2.72 \\
\hline Community Participation & 115 & 20.00 & 35.00 & 28.99 & 2.42 \\
\hline Justice & 115 & 16.00 & 40.00 & 32.72 & 2.80 \\
\hline Valid N (listwise) & 115 & & & & \\
\hline Source: primary data processed & & & & &
\end{tabular}

The results of descriptive statistical analysis show that the mean value is above the standard deviation which indicates good data and can be processed further.

\section{Data Quality Test Results}

Determination of data validity using Corrected Item-Total Correlation using SPSS. In this study $\mathrm{df}=\mathrm{n}-2(115-2)=113$, so we get $\mathrm{r}$ table for $\mathrm{df}(113)=0.183$. The item is stated to be valid if $r$ count> $r$ table. Reliability test using Cronbach alpha. a variable or construct is said to be reliable if the Cronbach Alpha value of each variable is> 0.70. (Ghozali, 2013).

Table 3. Validity and Reliability Test Results

\begin{tabular}{lcccc}
\hline \multicolumn{1}{c}{ Variable } & $\begin{array}{c}\text { Pearson } \\
\text { Correlation }\end{array}$ & Explanation & $\begin{array}{c}\text { Cronbach's } \\
\text { Alpha }\end{array}$ & Explanation \\
\hline $\begin{array}{l}\text { Village Government } \\
\text { Performance }\end{array}$ & $0.406-0.689$ & Valid & 0,780 & Reliable \\
\hline Transparency & $0.515-0.757$ & Valid & 0.751 & Reliable \\
\hline Accountability & $0.525-0.788$ & Valid & 0.833 & Reliable \\
\hline Community Participation & $0.592-0.833$ & Valid & 0.856 & Reliable \\
\hline Justice & $0.500-0.756$ & Valid & 0.838 & Reliable \\
\hline Source: primary data processed & & & &
\end{tabular}


The test results show the Pearseon correlation value for all variables has a value $>0.183$ which indicates that all variables are valid. Cronbach alpha value for all variables $>0.7$ which indicates that all are reliable. Furthermore, regression analysis can be performed.Hypothesis Testing Results The results of hypothesis testing can be seen in the table 4:

Table 4. Multiple Regression Analysis Results

\begin{tabular}{|c|c|c|c|c|c|}
\hline \multirow[t]{2}{*}{ Model } & \multicolumn{2}{|c|}{$\begin{array}{l}\text { Unstandardized } \\
\text { Coefficient }\end{array}$} & \multirow{2}{*}{$\begin{array}{c}\text { Standardized } \\
\text { Coefficient }\end{array}$} & \multirow[t]{2}{*}{$\mathrm{t}$} & \multirow[t]{2}{*}{ Sig } \\
\hline & $\mathrm{B}$ & Std Error & & & \\
\hline \multirow{2}{*}{$\begin{array}{l}\text { (Constant) } \\
\text { Transparency }\end{array}$} & .720 & .315 & & 2.284 & .024 \\
\hline & .280 & .079 & .295 & 3.557 & .001 \\
\hline Accountability & .167 & .078 & 193 & 2.133 & .035 \\
\hline $\begin{array}{l}\text { Community } \\
\text { Participation }\end{array}$ & .150 & .062 & .196 & 2.400 & .018 \\
\hline Justice & .240 & .051 & .328 & 4.710 & .000 \\
\hline
\end{tabular}

Dependent : Village Government Performance

Source: primary data processed

The results of hypothesis testing can be seen in table 4 . The results of testing hypothesis 1 show $\mathrm{p}$ value of the effect of transparency on performance is $0.001<0.005$ with a t value of $3.557>$ a critical value of 1.64 (one tail). The value of the $\beta$ coefficient is positive 0.295 . This shows that $\mathrm{H}_{1}$ is accepted, namely transparency has a positive effect on the performance of village government. It can be concluded that the higher the transparency of village government, the better the performance of village government in Meranti District.

The results of testing hypothesis 2 show $p$ value is $0.035<0.005$ with a t value $=2.133>$ a critical value of 1.64 (one tail) with a positive $\beta$ coefficient value of 0.193 . This indicates that $\mathrm{H}_{2}$ is accepted. It can be concluded that accountability has a positive effect on the performance of village government in Meranti Islands Regency. This shows that the better the accountability of the village government, the better the performance of the village government.

The results of testing hypothesis 3 show that the $p$ value is 0,018 and the $t$ value 2,400> the critical value of 1.64 (one tail) with a positive $\beta$ coefficient of 0.196 . This shows that $\mathrm{H}_{3}$ is accepted, namely community participation has a positive effect on the performance of the village government in Meranti Islands Regency. This shows that the higher the community participation, the better the performance of the village government will be.

The results of testing hypothesis 4 show that the $p$ value is $0.000<0.005$ with $t$ value $4.710>$ critical value of 1.64 (one tail) and the $\beta$ coefficient of 0.05 is positive 0.328 . This shows that $\mathrm{H}_{4}$ is accepted. Justice has a positive effect on the performance of village government in the Meranti Islands Regency. The results showed that the fairer the government to the community, the better the government's performance.

\section{Discussion}

The effect of transparency in improving performance

The test results show that transparency has an effect on the performance of the village government in Meranti district. The implementation of high transparency can improve the performance of the village government. Mardiasmo (2009) states transparency means the openness of the government in providing information related to public resource management activities to parties who need information. This means that the government is obliged to provide financial information and other information that will be used for decision making by interested parties

Werimon et al., (2007) also stated that the conceptual framework in building transparency in public sector organizations requires four components consisting of a financial 
reporting system, a performance measurement system, a public sector audit, and the functioning of public accountability channels. Transparency will then create horizontal accountability between the local government and the community so as to create a local government that is clean, effective, efficient and responsive to the aspirations and interests of the community which in turn will have an impact on improving performance (Nasution, 2018)

Supporting the stewardship theory that the village government as the agent entrusted by the community to manage the government, carries out its duties for the benefit of the community.. As a form of accountability, the village government provides the widest possible information to the community, starting from budgeting to implementing activities. Transparency creates good performance management so that it has an impact on improving performance. With transparency, the public can control the implementation of activities carried out by the government. Good cooperation between the government and the community has an impact on improving the performance of the village government.

In the village government in Meranti Regency, the application of transparency has not been fully implemented. There are still village governments that are considered less transparent. For example, in Banglas Village, the community considers that the village government is not transparent in the use of the Village Fund Allocation for a number of activities (hallo riau). This has an impact on the low public trust which results in and the lack of information causes the community to be unable to take part in making decisions for the implementation of village development.

The results of research Pande \& Putra (2017) and (Nasution, 2018) show that transparency has a positive effect on government performance. Transparency will increase public trust in the government and in return, the government will also provide the best service to the community, carry out programs and activities according to community needs. Lack of transparency will cause dissatisfaction for the community, so that the performance of public services will be considered bad in the eyes of the community, meaning that the village government has not succeeded in achieving its goals.

\section{The effect of accountability in improving performance}

The test results show that accountability has an effect on the performance of the village government in Meranti district. Implementation of high accountability has an impact on improving village government performance. Accountability is an important element and becomes a principle in the framework of realizing good governance.

Accountability is a form of the obligation of a person or organization to be accountable for the management and control of resources and the implementation of the policies entrusted to them (Novatiani et al., 2019). This study supports the stewardship theory which states that the government as an agent is the party who is given the authority to account for all its activities to the public and society to assess its implementation performance. This emphasizes the importance of accountability in improving the performance of village government. The existence of accountability in the implementation of village governance provides the opportunity for the community to know and control from budgeting to the implementation of activities. The village government must be able to account for and provide information to the community about government management which causes the government to always try to give its best performance because it will be assessed and monitored by the community.

The implementation of accountability in some villages in Meranti Regency is also still not optimal. Several development projects were deemed not to be in accordance with the planning. The project being worked on looks careless (hello riau). This shows that accountability is still low which results in the low performance of the village government in 
Meranti Regency. Therefore, it is important to apply accountability to the village government to create high village government performance.

This research is in line with research Putra ( 2018), Sukmawati \& Nurfitriani, (2019) and (Nasution, 2018) that accountability has a positive effect on government performance. Good accountability can improve the performance of public service organizations with job responsibilities as planned. The village government as a public service provider that is oriented to the interests of the community and the administration of public services must be able to be accountable for all of its work.

\section{The effect of community participation in improving performance}

The test results show that community participation affects the performance of the village government in Meranti district. The high participation of the community has an impact on improving the performance of the village government. According to (Mardikanto \& Soebianto, 2001) community participation is a form of community concern and responsibility for the importance of development which aims to improve their quality of life. Community participation shows that the implementation of activities must also benefit the community.

According to Stewardship theory, the government as a party is given the responsibility to manage the government, acting not for its own interests, but must benefit the parties concerned (Raharjo, 2007). This emphasizes that the village government must be able to accommodate all the interests of the community and must demonstrate its ability to achieve results that are in accordance with the interests of the community. This confirms that community involvement is closely related to the achievement of village government performance.

The principle of participation is key in an organization, both private and public. Participation encourages stakeholder involvement in various organizational affairs, in problem solving, or in other matters aimed at advancing organizational performance. This means that the more active the community is in the government process, the more successful the implementation of autonomy in a village will be, and the more autonomy that is achieved in a village will encourage the village government to strive for better performance. The results of this study are in line with (Putra, 2018) (Julianto \& Dewi, 2019) in their research it was also concluded that community participation had a significant effect on government performance. The higher the community participation, the higher the performance of the village government.

\section{The effect of justice in improving performance}

The test results show that justice affects the performance of the village government in Meranti district. The more fair the village government is to the community, the impact on improving the performance of the village government. Justice is the government's ability to provide welfare to the community in relation to its rights and obligations. If the principle of justice is properly implemented by the government, the public's trust in the government will be higher so that the government's performance will be better.

The principle of justice is a fair and equal treatment for the community in providing services that do not discriminate and do not discriminate against the people being served. A just government will provide equal opportunities to all people to improve and maintain the quality of life. Equity theory (Adam, 1963) also states that the fairness that individuals perceive can affect their assessment of the organization so that it will have an impact on organizational performance. Although research shows that fairness in organizations affects job satisfaction, in the context of the relationship between government and society, injustice to the government can lead to public dissatisfaction so that it will give a poor assessment of the government.

The relationship between justice and village government performance is explained by the sterawdship theory. Stewardship theory assumes a strong relationship between 
organizational success and owner satisfaction (Donaldson \& Davis, 1991). Steward (government) will protect and maximize the wealth of the government with the performance of the government, so that its utility function will be maximized. An important assumption of stewardship is that managers align their goals with those of owners(Raharjo, 2007)

In village government, steward is a village government whose role is to maximize the interests of the community. Therefore, justice for society needs to be upheld. If the community feels justice in the treatment of the village government both in terms of services and interests of the community, the government will get a good performance. This confirms that fairness is closely related to performance achievement. This research is in line with research conducted by (Jatmiko \& Lestiawan, 2016) in their research which also concluded that the principle of justice has a significant effect on government performance.

\section{CONCLUSION AND SUGESTION}

Based on the test results, several conclusions can be drawn. First, transparency has a positive effect on the performance of the Village Government in the Meranti Islands Regency. The more transparent the village government, the better the government's performance will be. In line with Nasution's opinion (2018), that transparency creates horizontal accountability between the local government and the community so as to create a local government that is clean, effective, efficient and responsive to the aspirations and interests of the community which in turn will have an impact on improving performance.

Second, accountability has a positive effect on the performance of village government in the Meranti Islands Regency, which shows that the more accountable the village government, the higher its performance. This study supports the stewardship theory (Donaldson, 1991) which states that the government as an agent is the party who is given the authority to account for all its activities to the public and society to assess its implementation performance. The government as an agent will maximize the interests of the community.

Third, community participation has a positive effect on the performance of village government in the Meranti Islands Regency, meaning that the higher the community participation, the higher the performance of the village government. Community participation from planning to supervision is very helpful in creating the performance of the village government. If the community does not participate at all in village development, then the possibility of development is not in accordance with the needs of the community.

Fourth, justice has a positive effect on the performance of the village government in the Meranti Islands Regency, meaning that the more equitable the village government is in managing its village, the more it will improve the performance of the village government in Meranti Regency. Fair treatment in the absence of discriminatory treatment and justice in obtaining rights and obligations can increase public trust which will ultimately improve the performance of the village government.

This research also has several limitations, namely the limited object of research, which is only conducted in villages in Meranti Regency. Retrieval of data in this study is only based on filling out the questionnaire so that it does not rule out the possibility that there are elements that are less objective in filling out the questionnaire, such as the existence of a joint filling in the questionnaire. In addition, in filling out the questionnaire, it was found that the respondents did not care about themselves and were not serious in answering the statements in the questionnaire. This study only uses the variables of transparency, accountability, community participation and justice so that there may be other variables that affect the performance of village government that need to be investigated.

For further researchers, it is suggested to further expand the population and sample used in the study, so as to produce better results. In data collection, it is necessary to complete oral 
and written questions and then the researcher can add other variables that affect the performance of the village government.

This research supports the stewardship theory proposed by (Donaldson \& Davis, 1991). According to management theory, the government is the party that is given the authority by the community to meet the needs of the community. Therefore, transparency, participation from the community, accountability and justice can help the village government realize the interests of the village community. The actions of the village government that prioritize the interests of the community have an impact on the positive assessment of government performance by the community. Community satisfaction with village government reflects good government performance. For the village government, this research has a performance contribution. The government must be able to implement good governance in village management so that optimal performance can be realized. 
IMPLEMENTATION OF GOOD GOVERNANCE TO IMPROVE THE PERFORMANCE OF VILLAGE GOVERNMENTS

Yesi Mutia Basri, Tusanti Igus Findayani and Arumega Zarefar

\section{REFERENCES}

Adrianto, N. (2007). Transparansi Dan Akuntabilitas Publik Melalui E Government. Bayumedia.

Antara. (2020). 473 Kepala Desa Terjerat Kasus Dana Desa Selama 2015-2019 Artikel Ini Telah Tayang Di Regional.Inews.Id Dengan Judul " 473 Kepala Desa Terjerat Kasus Dana Desa Selama 2015-2019", Klik Untuk Baca: Https://Regional.Inews.Id/Berita/473Kepala-Desa-Terjerat-. $\quad$ Https://Regional.Inews.Id/Berita/473-Kepala-Desa-TerjeratKasus-Dana-Desa-Selama-2015-2019

Arifani, C., Dr. Agustinus Salle, SE., M. E., \& Andika Rante, SE., M. S. (2018). Pengaruh Akuntabilitas, Transparansi Dan Pengawasan Terhadap Kinerja Anggaran Berbasis Value For Money (Studi Empiris Pada Pemerimtah Kota Jayapura). Jurnal Akuntansi \& Keuangan Daerah, 13(1), 68-81. Https://Doi.Org/Https://Doi.Org/10.52062/Jakd.V13i1.1426

Arthana, I. K. (2019). Analisis Faktor-Faktor Terjadinya Kecurangan (Fraud) Dalam Pengelolaan Dana Desa Pada Kecamatan Amabi Oefetotimur. Jurnal Akuntansi: Transparansi Dan Akuntabilitas, 7(1), 35-43. Https://Doi.Org/10.35508/Jak.V7i1.1302

Bastian, I., \& Suryadi. (2006). Akuntansi Sektor Publik : Suatu Pengantar. Erlangga.

Dayanandan, R. (2013). Good Governance Practice For Better Performance Of Community Organizations - Myths And Realities !! Journal Of Power, Politics \& Governance, 1(1), 10-26.

Donaldson, L., \& Davis, J. H. (1991). Stewardship Theory Or Agency Theory: CEO Governance And Shareholfer Returns. Australian Journal Of Management, June 1991, 49-66.

Fatimah, Mardani, R. M., \& Wahono, B. (2017). Pengaruh Good Corporate Governance Terhadap Nilai Perusahaan Dengan Kinerja Keuangan Sebagai Variabel Intervening). EJurnal Riset Manajemen Prodi Manajemen, 51-69.

Ferial, F., Suhadak, S., \& Handayani, S. (2016). Pengaruh Good Governance Terhadap Kinerja Keuangan Dan Nilai Perusahaan. Jurnal Administrasi Bisnis S1 Universitas Brawijaya, $33(1), 146-153$.

Indriana. (2019). Pengaruh Good Governance Terhadap Kinerja Keuangan Pemerintah Daerah Kabupaten Pangkajane Dan Kepulauan. Jurnal Ekonomi Invoice, 1(1), 1-28.

Jatmiko, B., \& Lestiawan, H. Y. (2016). Good Governance Government Andthe Effect On Local Governmentperformance (Survey On Gunung Kidul District Government Of Indonesia). International Journal Of Applied Business And Economic Research, 14(14), 981-997.

Jitmau, F., Kalangi, L., \& Lambey, L. (2017). Pengaruh Akuntabilitas, Transparansi Dan Fungsi Pemeriksaan Intern Terhadap Kinerja Pemerintah Daerah (Studi Empiris Di Kabupaten Sorong). Jurnal Riset Akuntansi Dan Auditing “Goodwill," 8(1), 276-285. Https://Doi.Org/10.35800/Jjs.V8i1.16036

Julianto, I. P., \& Dewi, G. A. K. R. S. (2019). Pengaruh Partisipasi Masyarakat, Penggunaan Sistem Keuangan Desa, Kompetensi Pendamping Desa Serta Komitmen Pemerintah Daerah Terhadap Keberhasilan Pengelolaan Dana Desa. Jurnal Ilmiah Akuntansi, 4(1), 24-42. Https://Doi.Org/10.23887/Jia.V4i1.17242

Kholmi, M. (2017). Akuntabilitas Pengelolaan Alokasi Dana Desa (Studi Di Desa Kedungbetik Kecamatan Kesamben Kabupaten Jombang). Journal Of Innovation In Business And Economics, 7(2), 143. Https://Doi.Org/10.22219/Jibe.Vol7.No2.143-152

Kuswanto, G. (2016). Pelaksanaan Good Governance Di Indonesia. In Http://Berita.Knkg- 
Indonesia.Org (P. 8). Http://Berita.Knkg-Indonesia.Org/2016/11/Pelaksanaan-GoodGovernance-Di-Indonesia.Html

Mahoney, T. A. Et Al. (1963). Development Of Managerial Performance: A Research Approach. Cincinnati: South Western Publ. Co.

Mahsum, M. (2012). Pengukuran Kinerja Sektor Publik. BPFE Yogyakarta.

Mardiasmo. (2009). Akuntansi Sektor Publik. Andi Offset.

Mardiasmo. (2018). Akuntansi Sektor Publik. Andi Offset.

Mardikanto, T., \& Soebianto, P. (2001). Pemberdayaan Masyarakat Dalam Perspektif Kebijakan Publik. Alfabeta, Bandung.

Nafidah, L. N., \& Anisa, N. (2017). Akuntabilitas Pengelolaan Keuangan Desa Di Kabupaten Jombang. Akuntabilitas, 10(2), 273-288. Https://Doi.Org/10.15408/Akt.V10i2.5936

Nasrun, M. (2019). Pengaruh Good Governance Terhadap Kinerja Keuangan Pemerintah Daerah Kabupaten Pangkajene Dan Kepulauan. Equilibrium: Jurnal Ilmiah Ekonomi, Manajemen Dan Akuntansi, 8(1), 19-26. Https://Doi.Org/10.35906/Je001.V8i1.330

Nasution, D. A. D. (2018). Analisis Pengaruh Pengelolaan Keuangan Daerah, Akuntabilitas Dan Transparansi Terhadap Kinerja Keuangan Pemerintah. Jurnal Studi Akuntansi \& Keuangan, 2(3), 149-162. Https://Ejurnal.Id/Index.Php/Jsak/Issue/View/26

Novatiani, A., Rusmawan Kusumah, R. W., \& Vabiani, D. P. (2019). Pengaruh Transparansi Dan Akuntabilitas Terhadap Kinerja Instansi Pemerintah. Jurnal Ilmu Manajemen Dan Bisnis, 10(1), 51-62. Https://Doi.Org/10.17509/Jimb.V10i1.15983

Pande, I. M., \& Putra, D. (2017). Pengaruh Prinsip-Prinsip Good Corporate Governance, Motivasi, Dan Budaya Organisasi Terhadap Kinerja Karyawan. E-Jurnal Akuntansi, 21, 1660-1688. Https://Doi.Org/10.24843/EJA.2017.V21.I02.P29

Pertiwi, D. P. (2015). Pengaruh Akuntabilitas, Transparansi, Dan Pengawasan Terhadap Pengelolaan Anggaran Berkonsep Value For Money Pada Instansi Pemerintah (Studi Empiris SKPD Provinsi Riau). Jom FEKON, 2(2), 1-15.

Putra, W. E. (2018). Analisis Pengaruh Pengawasan Fungsional, Akuntabilitas Publik Dan Peningkatan Pelayanan Publik Terhadap Kinerja Pemerintah Daerah (Studi Empiris Pada SKPD Di Provinsi Jambi). Jurnal Akuntansi Dan Pajak, 18(2), 181. Https://Doi.Org/10.29040/Jap.V18i2.143

Raharjo, E. (2007). Teori Agensi Dan Teori Stewardship Dalam Perspektif Akuntansi. Fokus Ekonomi, 2(1). Https://Doi.Org/10.34152/Fe.2.1.\%25p

Setiawan, H., \& Safri, M. (2016). Analisis Pengaruh Akuntabilitas Publik, Transparansi Publik Dan Pengawasan Terhadap Kinerja Satuan Kerja Perangkat Daerah Di Kabupaten Bungo. Jurnal Perspektif Pembiayaan Dan Pembangunan Daerah, 4(1), 51-72. Https://Doi.Org/10.22437/Ppd.V4i1.3533

Sopanah, A., \& Mardiasmo. (2003). Pengaruh Partisipasi Masyarakat Dan Transparansi Kebijakan Publik Terhadap Hubungan Antara Pengetahuan Dewan Tentang Anggaran Dengan Pengawasan Keuangan Daerah. Simposium Nasional Akuntansi VI.

Soukotta, V., \& Utami, I. (2019). Apakah Gaya Kepemimpinan Mendukung Potensi Pengungkapan Kecurangan Pengelolaan Dana Desa? Jurnal Online Insan Akuntan, 4(2), 223-238.

Sukmawati, F., \& Nurfitriani, A. (2019). Pengaruh Transparansi Dan Akuntabilitas Terhadap Pengelolaan Keuangan Desa ( Studi Pada Pemerintah Desa Di Kabupaten Garut ). Jurnal Ilmiah Bisnis, Pasar Modal, Dan UMKM, 2(1), 52-66.

Supriatna, N., \& M. Kusuma, A. (2009). Pengaruh Good Corporate Governance Terhadap Kinerja Perusahaan. Jurnal ASET (Akuntansi Riset), $1(1), 1$. Https://Doi.Org/10.17509/Jaset.V1i1.8907

Susanti, I. (2014). Pengaruh Good Governance, Pemanfaatan Teknologi Informasi Dan Pengendalian Intern Terhadap Kinerja Organisasi (Studi Pada Skpd Kabupaten Siak). 
IMPLEMENTATION OF GOOD GOVERNANCE TO IMPROVE THE PERFORMANCE OF VILLAGE GOVERNMENTS

Yesi Mutia Basri, Tusanti Igus Findayani and Arumega Zarefar

Jurnal Online Mahasiswa Fakultas Ekonomi Universitas Riau, 1(1), 1-14.

TNP2K. (2020). Kemajuan Pembangunan Desa: Kinerja Pemerintah Desa Ataukah Dampak Spasial? Buletin Tim Nasional Percepatan Penanggulangan Kemiskinan, 01, 5-10.

Tolok, A. D. (2021). Mendes PDTT Dorong Desa Di Kabupaten Meranti Jadi Pilot Project Sgds. Bisnis.Com. Https://Kabar24.Bisnis.Com/Read/20210316/15/1368366/MendesPdtt-Dorong-Desa-Di-Kabupaten-Meranti-Jadi-Pilot-Project-Sgds

Werimon, S., Ghozali, I., \& Nazir, M. (2007). Pengaruh Partisipasi Masyarakat Dan Transparansi Kebijakan Publik Terhadap Hubungan Antara Pengetahuan Dewan Tentang Anggaran Dengan Pengawasan Keuangan Daerah (APBD) (Study Empiris Di Provinsi Papua). SNA X Makassar. 